İş ve İnsan Dergisi I The Journal of Human and Work

Y1l | Year: Ekim | October 2018

Cilt-Sayı | Volume-Issue: 5 (2)

ss I pp: $157-168$

doi: $10.18394 /$ iid. 349410

e-ISSN 2148-967X

http://dergipark.gov.tr/iid/

Araştırma Makalesi

\title{
Öğrenci Kariyer Yapılandırma Envanteri’nin Türkçe Uyarlaması: Geçerlik ve Güvenirlik Çalışması
}

\author{
Adaptation of the Student Career Construction Inventory into Turkish: A Validity and \\ Reliability Study
}

Abdullah Sevinç a , Diğdem Müge Siyez ${ }^{*}, \mathrm{~b}$

MAKALE BILGIISİ

Anahtar Kelimele:

Kariyer, Kariyer

Yapılandirma, Geçerlik,

Güvenirlik, Uyarlama

\section{Tarihler:}

Geliş 05 Kasım 2017

Düzeltme geliş 16 Mart 2018

Kabul 28 Mart 2018

\begin{abstract}
ÖZ
Bu çalışmanın amacı Öğrenci Kariyer Yapılandırma Envanteri’nin (ÖKYE) Türkçeye uyarlanarak üniversite ögrencileri için geçerlik ve güvenirliğinin incelenmesidir. Araştırmanın çalışma grubunu Dokuz Eylül Üniversitesi’nde öğrenim gören 309 ögrenci (161 kadın, 158 erkek) oluşturmaktadır. ÖKYE' nin geçerlik çalıșması kapsamında doğrulayıcı faktör analizi yapılmış ve eş değer ölçek geçerliği incelenmiştir. Doğrulayıcı faktör analizi sonucunda ü̧ faktörlü yapının uyum indekslerinin daha iyi olduğu belirlenmiştir. Eș değer ölçek geçerliğ sonucunda da ÖKYE' nin alt boyutlart ile Kariyer Uyum Yetenekleri Ölçeği' nin alt boyutlar arasında pozitif yönde istatistiksel olarak anlamlı ilişskiler bulunmuştur. Ölçeğin Cronbach alfo güvenirlik katsaylsı .87 bulunurken Belirginleştirme" alt boyutu için $\alpha=.65$, "Keşfetme" alt boyutu için $\alpha=.72$ ve "Hazır Olma" ve "Karar verme" alt boyutu için $\alpha=.87$ olarak bulunmuştur. Sonuç olarak üniversite ögrrencilerinin kariyer seçimi konusunda tutumlarını, yeterliliklerini ve inançlarını ölçmede Öğrenci Kariyer Yapılandırma Envanteri' nin yeterli geçerlik ve güvenirlik değerlerine sahip olduğu söylenebilir.
\end{abstract}

\section{ART I C LE INFO}

\section{Keywords:}

Career, Careerconstruction,

Validity, Reliability,

Adaptation

Article history:

Received 05 November 2017

Received in revised form 16

March 2018

Accepted 28 March 2018

\begin{abstract}
A B S T R A C T
The aim of this study was to adapt the Student Career Construction Inventory (SCCI) into Turkish language and examine the reliability and validity among university students. After completing translation and back translation studies, SCCI was administered 309 students (161 female and 158 male) from Dokuz Eylül University. In order to assess the validity of the SCCI, confirmatory factor analysis and concurrent validity were conducted. Results indicated that three-factor structure better fit data. Regarding concurrent validity SCCI and their subscales are positively correlated with the sub-dimensions of the Career Adapt Ability Scale. The Cronbach alpha internal consistency coefficent was .65 for Crystallizing subscale, .72 for Exploring subscale, .87 for Deciding subscale and .87 for all the scale. As a result, SCCI has enough validity and reliability values form easuring attitudes, qualifications and beliefs of universty students about career choice.
\end{abstract}

a İletişim Kurulacak Yazar, Yükssek Lisans Öğrencisi, Dokuz Eylül Üniversitesi Eğitim Bilimleri Enstitüsü, İzmir, Türkiye. E-mail: abdullahsvnc@outlook.com.ORCID:0000-0001-2345-6789

${ }^{*}$, P Prof. Dr. Dokuz Eylül Üniversitesi Buca Eğitim Fakültesi, İzmir, Türkiye.E-mail: didem.siyez@gmail.com. ORCID: 0000-00022345-6789 


\section{GİRIŞ̧}

Kariyer, en genel tanımıyla bireylerin yaşamları boyunca oynadığ 1 rollerin, yaptığı işlerin, kendisine başarı kazandırmış olan önemli bir kombinasyonu ve yaşamımızdaki sınırlı bir süreden ziyade bütün yaşamımızı kapsayan bir süreçtir. Bu süreç, ömür boyu yaşanan olaylarla, mesleki ve diğer rollerin birbirini izlemesi sonucu oluşan durumlarla ve mesleki gelişim boyunca yaşanan ilerlemeler, duraklamalar ve gerilemelerle şekillenmektedir (Kuzgun, 2006; Özyürek, 2013; Super, 1980).

Bireyler için kariyer, gerçekleştirilmesi gereken bir tercih süreci ve aynı zamanda önemli bir sorumluluktur. $\mathrm{Bu}$ sürecin yeterince açık ve kolay olmaması bireylerin kariyer seçim süreçlerini zorlaştırmakta ve ileride sahip olacakları hayatın refah düzeyini etkilemektedir (Gottfredson, 2002). Üniversite dönemi ise öğrencilerinin kişilik özellikleriyle çalışmayı hedefledikleri işler arasındaki uyumu sağlamaları kariyerleri açısından büyük önem taşımaktadır. Özellikle mezuniyetten sonra iş/eğitim seçiminde yaşanan sıkıntılar öğrencilerin kariyer konusunda yardıma ihtiyaç duyduklarını göstermektedir. Üniversite eğitimi sırasında alınan kariyer danışmanlığı öğrencileri iş dünyasına hazırlama ve yaşam rollerini uygun bir yaşam stiline uyarlama konusunda yardımcı olmaktadır (Osborn \& Zunker, 2002). Öğrencilik döneminden itibaren kariyer planlamaya başlayan öğrenciler mezuniyet sonrasında iş bulma, çalışılacak alanla ilgili yeteneklerini geliştirme ve profesyonel yaşama uyum sağlama gibi konularda daha avantajlı hale gelmektedirler. (Kozak \& Dalkıranoğlu, 2013).

Bireylere kariyerle ilgili konularda yardımcı olmak amacıyla çok sayıda kuram geliştirilmiştir. Yeşilyaprak (2011) geliştirilen bu kuramları bireylerde meslek fikrinin doğuşunu, gelişimini, mesleki seçim ve kararın oluşma biçimlerini, bu seçimi etkileyen faktörleri ve de bu seçim sürecini açıklamaya çalışan bilimsel görüşler olarak tanımlamaktadır. Bacanlı'ya (2011) göre kariyer danışmanlığı alanında en eski yaklaşım olarak kabul edilen Parsons' un (1909) Özellik ve Etmen Kuramı'ndan başlayarak kariyer seçim sürecini (örn. Holland'ın Tipoloji Yaklaşımı) ya da kariyer gelişimini (örn. Super'ın (1980) Yaşam BoyuYaşam Alanı Kuramı, Gottfredson'un (2002) Daraltma Uzlaşma Kuramı) açıklamaya yönelik birçok kuram geliştirilmiştir. Özellik ve Etmen Kuramı bireysel özelliklerin ve mesleklerin birlikte değerlendirildiği bir yaklaşımdır. Meslek seçiminin 3 aşamalı bir süreç olduğunu savunan bu yaklaşıma göre bireyler tarafindan kendilerine ait tutumlar, yetenekler, ilgiler, sahip olunan kaynakların sınırlılıkları ve nedenleri testler aracılığıyla öğrenilir. İkinci aşamada ise farklı çalışma alanlarıyla ilgili bilgiler, gereklilikler, koşullar, avantajlar, dezavantajlar, firsatlar ve ihtimaller öğrenilir. Son olarak ise ilk iki aşamada edinilen bilgiler eşleştirerek akıl yürütülür ve meslek tercih süreci tamamlanmış olur (Parsons, 1909'dan aktaran Sharf, 1992).

Kariyer gelişimini açıklayan diğer bir kuram ise Holland (1966) tarafından geliştirilen tipoloji kuramıdır. Bu kuram bireylerin mesleki tercihlerini, kişiliği ve kişilik gelişimini açıklamayı hedeflemektedir. Tipoloji kuramına göre 6 adet çevre tipi vardır. Bunlar; gerçekçi, sosyal, geleneksel, sanatçı, araştırmacı ve girişimci çevredir. Aynı mesleği seçen bireyler meslek gruplarını oluşturmaktadırlar ve bireylerin kişilik özellikleri de paylaştıkları ortamla ilişkilidir. Her ortamda belli bir kişilik tipi hakimdir ve bu kişilik tipleri hakim oldukları çevreyle aynı ismi taşımaktadırlar (Holland, 1966, 1973).

Yaşam Boyu - Yaşam Alanı kuramını geliştirerek kariyer gelişimini inceleyen Super (1953) yaşam boyu süren kariyer aşamalarını büyüme, araştırma, yerleşme, devam ettirme ve çöküş evreleri diye adlandırmaktadır. $\mathrm{Bu}$ evreler bireylerin gerçekleştirmeleri gereken görevleri içermektedir ve başarılı bir şekilde gerçekleştirilemeyen görevler diğer evrelere geçişi zorlaştırmaktadır. İnsanlar bu evrelerden geçerken birtakım roller üstlenirler. Bunlar, çocuk, öğrenci, boş zaman, vatandaş, çalışan, eş, anne, baba, ebeveyn, emekli vb. gibi rollerdir. Bireylerin bu rolleri sergiledikleri ev, toplum, okul, işyeri, kilise, emekliler kulübü gibi alanlara ise tiyatro denmektedir. Bireylerin üstlendikleri bazı roller ve kullandıkları bazı tiyatrolar diğerlerine göre daha baskın olurken bazıları ise bireyin yaşamında daha az yer kaplayabilir. Ev kadını olarak çalışan bir bireyin aynı zamanda kiliseye gitmesi üstlendiği birden fazla rol olduğunu göstermektedir. Aynı şekilde ev kendisi için ana tiyatro sahnesiyken kilise kendisi için daha az kullandiğ 1 ikinci bir tiyatrodur. Bireylerin yaşam döngüsü içerisinde üstlendikleri roller ve bu rolleri oynadığı tiyatrolar sahip oldukları yaşam alanlarını oluşturmaktadır (Super, 1953, 1975, 1980).

İçinde bulunduğumuz çağda yaşanan hızlı gelişmeler ve teknoloji dünyasında gerçekleşen ilerlemeler sosyal ve özel yaşamda, eğitimde ve birçok alanda yaşam biçimlerinin değişime uğramasına neden olmaktadır. Bilginin üretilmesi ve kullanılması konusunda yaşanan gelişmeler ise eğitim, kariyer, çalışma hayatı gibi alanları derinden etkilemektedir. Maree'ye (2015) göre özellikle durağan bir iş yapısının yerini daha hareketli bir iş 
yapısına bırakması çalışanların belirsizlik, güvensizlik, iş travması ve sıkışmışlık duygusu gibi sorunlar yaşamasına neden olabilmektedir. Kariyer ve çalışma hayatında yaşanan gelişmeler ve değişimler kariyer kuramlarını da etkilemeye başlamıştır. Dix'e (2018) göre kariyer yapılandırma süreci, 20. yüzyılın başlarından itibaren mesleki rehberliğin değişen ekonomik ve kültürel koşullara cevap vermesiyle kendi evrimini başlatmıştır. 21 . yüzyılın başlarında ise kariyer konusunda çalışan bazı akademisyenler iş dünyasıyla ilgili yeni toplumsal düzenlemelere ihtiyaç duyulduğunu fark etmişlerdir (Savickas vd., 2009). Tüm bu gelişmelerin etkisiyle son yıllarda post modern temelli yaklaşımlar olan yapılandırmacı yaklaşımlar ve var olan kariyer danışmanlığı kuramlarının işlevsel yanlarını birleştirmeyi benimseyen bütünsel yaklaşımlar ön plana çıkmaya başlamıştır. Brown'un (2002) Değer Temelli Kariyer Yaklaşımı, Brott'un (2001) Kendi Hikayeni Oluşturma Yaklaşımı ve Savickas vd. (2009) tarafından geliştirilen Yaşam Düzenleme Psikolojik Danışmanlığı Yaklaşım Kuramı yapılandırmacı yaklaşımın etkisiyle geliştirilen kuramlardır. Patton ve McMahon (1999) tarafından geliştirilen Sistemler Kuramı Çerçeve Çalışması ve Savickas (2002) tarafından geliştirilen Kariyer Yapılandırma Kuramı ise mevcut kuramları bütünleştirmeyi benimseyen yaklaşımlardır (Korkut-Owen \& Niles, 2011).

Yaşanan bu gelişmelerin etkisiyle Savickas ve arkadaşlarının (2009) kariyer teorilerinin ve mesleki rehberlik tekniklerinin 20. yüzyılda kullandıkları temel kavramları postmodern ekonomiye uyum sağlayabilmeleri için yeniden formüle edilmesi gerektiğini belirtmektedirler. Fakat günümüzdeki mevcut yaklaşımlar bu konuda yeterli değildir. İlk olarak, mevcut yaklaşımlar bireylerin kişisel özelliklerinin durağan olduğu varsayımına dayanmaktadır ve güvenli diye tanımladığı meslekleri belli alanlarla sınırlamıştır. İkinci olarak, mevcut görüşler kariyeri sabit dizilmiş aşamalar olarak kavramsallaştırmaktadır. Mesleki kimlik, kariyer planı, kariyer gelişimi ve kariyer aşamaları insanların iş çevrelerine uyumunu tahmin etmek için kullanılmaktadır ve bunu yaparken iş çevrelerinin ve insan davranışlarının durağan olduğu varsayımına dayanılmaktadır.

Tüm bu gelişmelerin etkisiyle günümüzde kariyer gelişimini yeniden formüle etmeye çalışan bazı yaklaşımlar ortaya çıkmıştır. Bu yaklaşımlardan biri olan kariyer yapılandirma kuramı, Super'ın mesleki gelişim kuramının belirsiz ve genişletilmiş bir versiyonu olarak çok kültürlü toplumlarda ve küresel ekonomide kullanılmak için güncellenmiş ve geliştirilmiştir. Sosyal yapılandırmacılığı bir meta-teori olarak kullanıp mesleki gelişim kuramının ana kavramlarını yeniden tanımlamıştır. Böylece Super'in yenilikçi düşüncelerini günümüzdeki kariyer kuramlarıyla birleştirmiştir. $\mathrm{Bu}$ kuram Holland'ın tipoloji yaklaşımını ve Super'ın gelişim dönemlerini kabul edip kullanmaktadır. Kariyer yapılandırma kuramında en göze çarpan yenilik Super'ın mesleki gelişim kuramındaki koruma evresinin değişimidir. (Savickas, 2002, 2005). Kariyer yapilandırma teorisi, mesleki seçim, uyum, meslek seçim sürecinde eşleştirmeler yapmak ve bu eşleştirmeleri anlamlı hale getirmek gibi konuları inceleyen bir yaklaşımdır (Hartung \& Taber, 2008). Kariyer yapılandırma kuramı, bireysel gelişim, psikodinamik motivasyon ve bireysel farkl1lık konularını birleştirerek kariyer konusunda büyük bir meta-teori oluşturmuştur. Böylece mesleki davranışlar konusunda kapsayıcı bir ortaya çıkmıştır (Maree, 2010).

Kariyer yapılandırma teorisi, organizmik dünya görüşünü bağlamsal dünya görüşü olarak değiştirmiş ve böylece 20. yüzyılda ortaya çıkmış olan kariyer kuramlarını bu konuda güncellemiştir (Savickas, 2002). Son yillarda kariyer yapılandırmacılığı kuramından hareketle kariyer sürecini değerlendirmek amacıyla bazı ölçme araçları geliştirilmeye başlanmıştır. Bunlardan biri Savickas ve Porfeli (2012a) tarafindan üniversite öğrencilerine yönelik olarak geliştirilen Öğrenci Kariyer Yapılandırma Envanteri'dir (ÖKYE). Bu ölçek, belirginleştirme, mesleki keşif, kariyer kararı verme, beceriler ve okuldan işe geçiş isimli 5 alt boyuttan ve 25 maddeden oluşmaktadır. ÖKYE'nin 25 maddelik hali Portekizceye (Rocha \& Guimaraes, 2012), İspanyolcaya (Merino-Tejedor, Hontangas-Beltran \& Boada Grau, 2016), Hırvatça (Barbarović \& Sverko, 2016) ve Finceye (Ryba, Zhang, Huang \& Aunolaa, 2016) uyarlanmıştır. Bu uyarlama çalışmalarından da ölçeğin geçerli ve güvenilir bir ölçme aracı olduğu fakat faktör yapılarının ülkelere göre farklılık gösterdiği sonucuna ulaşılmıştır.

Savickas, Porfeli, Hilton ve Savickas (2018) tarafından daha kısa fakat aynı ölçme gücüne sahip bir ölçek geliştirmek amacıyla ÖKYE' nin madde sayıs1 18'e düşürülerek okuldan işe geçiş boyutu ölçekten çıkarılmıştır. Sonuç olarak ÖKYE, belirginleştirme, keşfetme, karar verme ve hazırlık yapma olarak dört boyuttan oluşmaktadır. Belirginleştirme alt boyutu, kişinin kendi ilgi, yetenek ve değerlerine ilişkin tanımlamalar yapabilmesini değerlendirmektedir. Keşfetme alt boyutu, farklı meslekler ve iş kolları hakkında bilgi edinme ile ilgilidir. Kara verme boyutu, kişinin meslekle ilgili bir iş kolu belirlemesi ve işe girmesi ile ilgilidir. Hazırlık alt boyutu ise hoşlandığı bir iş 
alanı ve meslek belirlemek ve bu alanda eğitime başlamakla ilgilidir.

Orijinal ölçeğin geliştirildiği ülke olan Amerika Birleşik Devletleri, her eyaletin kendine özgü bir sistem kurduğu merkezi otoriteden uzak bir eğitim sistemine sahiptir. Zorunlu eğitim ilköğretim ve ortaöğretimden oluşmaktadır ve süresi 12 yıldır. İlköğretimden ortaöğretime geçişte sinav zorunluluğu olmamakla birlikte düzenli olarak yönlendirme hizmeti sunulmaktadır. Benzer şekilde yükseköğretim kademesine geçişte de sınav bulunmamaktadır ve her üniversite kendi sınav ve değerlendirmelerini yaparak öğrencilerini kendileri seçmektedir. Amerika'da mesleki ve teknik eğitim oldukça fazla çeşitliliğe sahiptir. Türkiye'den farklı olarak bu eğitimlerden faydalanmak için belirli ücretler ödemek gerekmektedir (Baş, 2016). Zorunlu eğitimin ardından bazı öğrenciler "community college" adındaki okulları tercih edip 2 yıllık mesleki eğitimin ardından ön lisans derecesi elde etmektedirler. Bazı öğrenciler ise 1 yıllık eğitim veren ve mesleki eğitim sertifikası veren özel okulları tercih edebilmektedirler. Bireyler aldıkları mesleki eğitimin ardından dilerlerse akademik yükseköğretim adı altında sırasıyla lisans, yüksek lisans ve doktora eğitimi alabilmektedirler (NCES, 2003).

Diğer yandan Türk eğitim sistemi, Milli Eğitim Bakanlığı (MEB) tarafından yönetilen merkezi bir yapıya sahiptir. Ülke genelinde yürütülen tüm eğitim faaliyetleri bakanlığın kontrolü altındadır. Zorunlu eğitimin 8 yıldan 12 yıla yükseltildiği bu sistemde 4+4+4 uygulamasına geçilmiştir. İlk 4 yılı oluşturan ilkokulun tamamlanmasının ardından öğrenciler kendi ilgi ve isteklerine uygun okullara giderek 4 yıllık ortaokul eğitimi almaktadırlar. Ortaokul eğitiminden lise eğitimine geçiş aşamasında öğrenciler bir sınava tabi tutulmaktadırlar ve zorunlu eğitimin son halkasını 4 yıllık lise eğitimiyle tamamlamaktadırlar (Çam, 2015). Üniversite eğitimi alabilmek için ise Yükseköğretim Kurumları Sınavı'nda (YKS) başarılı olmak zorundadırlar. Türkiye'de yükseköğretim eğitimi ortaöğretime dayalıdır ve en az iki yıllık yüksek öğrenim veren bütün eğitim kurumları bu kapsama girmektedir. Bu yap1 Türk toplumunun seviyesini arttırmayı ve bilimsel verilerle kamuoyunu aydınlatmayı hedefleyen fakülte, enstitü, yüksekokul, konservatuar, meslek yüksekokulu ile uygulama ve araştırma merkezleri gibi kurumlardan oluşmaktadır. (Baş, 2016; Polat, 2008). Özetle ülkemizdeki lise mezunu gençler herhangi bir yükseköğretim kurumuna geçiş yapabilmek için merkezi sınavlara girmek zorundadırlar. Bu geçiş sürecinde gençler meslek seçimlerini büyük oranda tamamlamış olmaktadırlar. (Külekçi \& Bulut, 2010; Yılmaz, 2016). Bu durum Türk eğitim sistemiyle ABD eğitim sistemi arasındaki temel farklılıklardan biridir. Ayrıca Türkiye'deki öğrencilerin lise
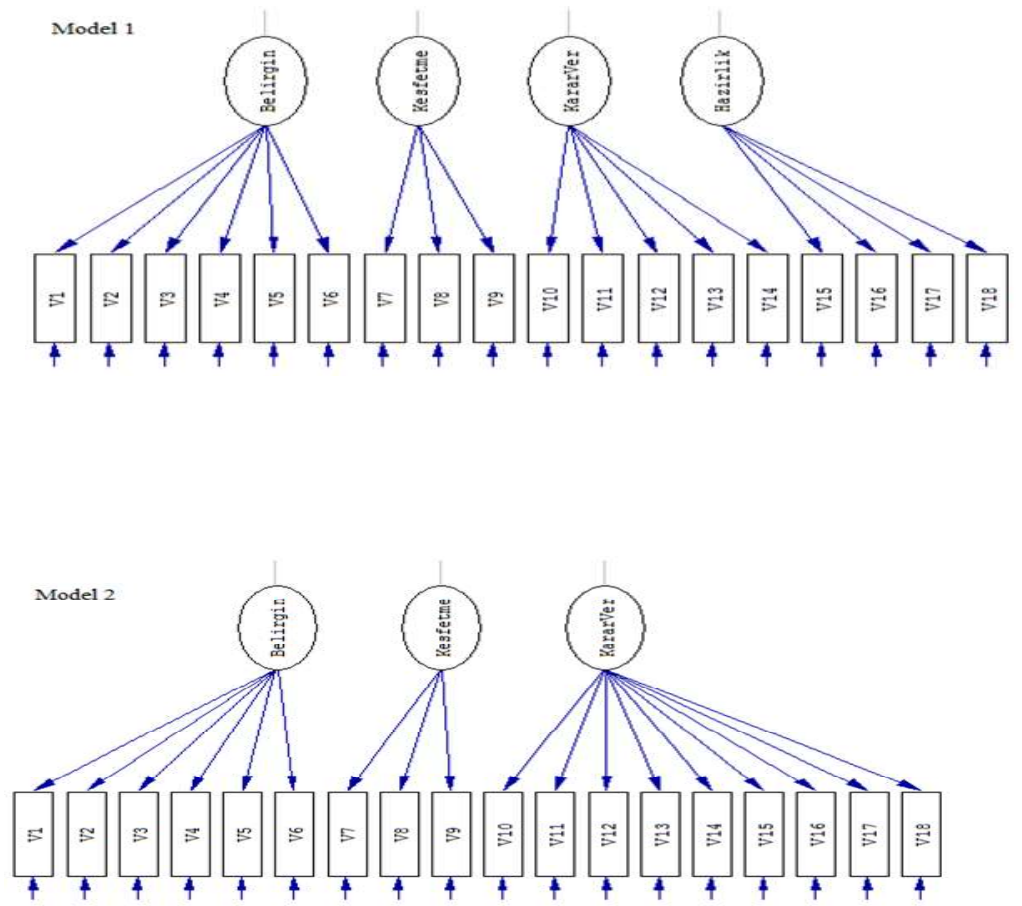
eğitimlerini tamamladıktan hemen sonra üniversite eğitimine başlamakta ve lise sürecinde meslek tercihlerini büyük oranda tamamlamış olmaktadırlar. $\mathrm{Bu}$ farklılıkların Türkiye'deki öğrencilerin kariyer yapılandırma sürecinin hazırlık yapma evresini ABD'li gençlerden daha farklı algılamalarına neden olduğu düşünülmektedir.

$\mathrm{Bu}$ araştırmanın amacı Öğrenci Kariyer Yapılandırma Envanteri'nin Türkçe'ye uyarlanarak geçerlik ve güvenirlik çalışmasının yapılmasıdır. Hem ÖKYE'nin farklı ülkelerde farklı faktör yapılarının ortaya çıkması, hem de Türk eğitim sistemindeki farklılıklara bağlı olarak üniversite öğrencilerinin kariyer yapılandırmalarının da farklı olabilecek olması nedeniyle ÖKYE'nin Türkçe formunun yapı geçerliği doğrulayıcı faktör analizi ile incelenirken iki alternatif model belirlenmiştir (Bkz. Şekil 1). Model 1, 18 maddeden oluşan ÖKYE'nin dört faktörlü modelinin (belirginleştirme, keşfetme, karar verme ve hazırlık) test edilmesine dayanmaktadır. Model 2 ise Türk eğitim sistemine daha uygun olacağı düşünülen üç faktörlü modeldir. Üç faktörlü bir modelde, belirginleştirme ve keşfetme boyutları olduğu gibi korunurken, karar verme ve hazırlık boyutları tek bir boyut olarak ele alınmaktadır. Bu modelin üretilmesinin sebebi Türkiye'de öğrencilerin üniversite eğitimine başlamasıyla birlikte meslekte karar verme hazırlık süreçlerinin de eş zamanlı başlamasından kaynaklanmaktadır.

\section{YÖNTEM}

\section{1. Çalıșma Grubu}

Araştırmanın çalışma grubu, basit tesadüfi örnekleme yöntemiyle belirlenen Dokuz Eylül Üniversitesi'nde öğrenim gören 161'i (\%52.1) kadın, 158'i (\%47.9) erkek olmak üzere, toplam 309 öğrenciden oluşmaktadır. Üniversite öğrencilerinin yaş aralığ $18-48(\overline{\mathrm{x}}=21.53, \mathrm{ss}=2.47)$ arasında değişmektedir. Katılımcıların 89'u (\%28.8) birinci sınıfa, 80'i (\%25.9) ikinci sınıfa, 78'i üçüncü sinıfa (\%25.2) ve 62'si (\%20.1) dördüncü sinıfa devam etmektedir.

\subsection{Veri Toplama Araçları}

\subsection{1. Öğrenci Kariyer Yapılandırma Envanteri (ÖKYE)}

Üniversite öğrencilerinin kariyer seçimi konusunda tutumlarını, yeterliliklerini, inançlarını ölçmek yerine baş etme davranışlarını ölçmek amacıyla Savickas ve arkadaşlarının (2018) tarafından geliştirilen ÖKYE, 18 maddeden oluşmaktadır.
Ölçek maddeleri beşli Likert (1= Henüz Bunun Hakkında Düşünmedim, 5= Bunu Zaten Yaptım) ile değerlendirilmektedir. ÖKYE'den en düşük 18, en yüksek 90 puan alınabilmektedir. Ölçekten alınan puanın artması bireyin kariyerini oluşturmak için yapması gereken mesleki davranışları gerçekleştirdiği anlamına gelmektedir. Ölçek geliştirilirken yap1 geçerliliği kapsamında 996 öğrenciyi iki gruba ayırıp yarısına açımlayıcı faktör analizi (AFA) diğer yarısına ise doğrulayıcı faktör analizi (DFA) uygulanmıştır. Uygulanan ana eksen faktörizasyon yöntemine göre toplam 18 maddeden oluşan 4 faktörlü (belirginleştirme, keşfetme, karar verme, hazırlık yapma) yapı doğrulanmıştır. Türkçe'ye uyarlanan bu 4 faktörlü yapının maddeleri Ek-1'de yer almaktadır.

\subsection{2. ÖKYE’nin Dil Geçerliği}

Savickas ve arkadaşlarının (2018) tarafından revize edilen Öğrenci Kariyer Yapılandırma Envanteri’nin Türkçeye uyarlanması kapsamında ilk olarak ölçeğin geliştiricilerinden olan Mark Savickas'tan e-posta aracılığıyla izin alınmıştır. Alınan iznin ardından Brislin'in (1970) geri çeviri yöntemi kullanılarak ölçme aracının dil geçerliliği yapılmıştır. Buna göre ilk olarak Rehberlik ve Psikolojik Danışmanlık bölümünde yüksek lisans eğitimine devam eden, iyi derecede İngilizce bilen ve kariyer psikolojik danışmanlığı dersi alan 3 öğrenci tarafindan ölçek maddeleri Türkçeye çevrilmiştir. Yine aynı bölümde görev yapan ve iyi derecede İngilizce bilen bir akademisyen tarafından çeviriler incelenmiş ve ortak bir form oluşturulmuştur. İkinci aşamada oluşturulan Türkçe form alandaki iyi derecede İngilizce bilen farklı bir akademisyene gönderilmiş ve maddeler tekrar İngilizceye çevrilmiştir. Son aşamada ise Türkçeden İngilizceye çevrilmiş hali Savickas'a gönderilmiş ve Türkçeden İngilizceye çevrilen form ile orijinal maddelerin anlamsal denkliğine ilişkin onay alınmıştır

\subsubsection{Kariyer Uyum Yetenekleri Ölçeği (KUYÖ)}

Savickas ve Porfeli (2012b) tarafindan geliştirilen Kariyer Uyum Yetenekleri Ölçeği, bireylerin sahip oldukları mesleğe ilişkin rollere uyum düzeyini, mesleği için gerekli olan becerileri edinme seviyesini ve gelecekteki meslek yaşamına hazır olma durumunu ölçen bir araçtır ve 13 ülkeyi kapsayan bir araştırmanın sonucunda geliştirilmiştir. Pilot çalışmada 55 maddeye sahip olan ölçeğe açımlayıcı faktör analizi uygulanmış ve madde sayısı 24'e düşmüştür. AFA'dan elde edilen sonuca göre kaygı, kontrol, merak ve güven olarak 4 faktörlü bir yapı oluşturulmuştur. Ardından farklı ülkelerdeki sonuçların uygunluğunu belirlemek için DFA ile Ortalama ve Kovaryans Yapısal Analizi 
(MACS) kullanılmış ve uygun olduğuna karar verilmiştir. KUYÖ, Beşli Likert tipi (5= Kesinlikle Katılmıyorum, 1= Kesinlikle Katıllyorum) ölçek aracılığıyla derecelendirilmektedir. Ölçekten alınabilecek en düşük puan 24 , en yüksek puan ise 120 'dir. Ölçekten alınan puanın artması bireyin mevcut ve yakın gelecekteki mesleki gelişim görevlerinin, iş değişimlerinin ve stres düzeylerinin üstesinden gelebilmesini sağlayacak becerileri edindiğini ve bu durumlara hazır olduğunu göstermektedir.

Kariyer Uyum Yetenekleri Ölçeği' nin Türkçeye uyarlaması Kanten (2012) tarafindan yapılmıştır. Yapılan uyarlama çalışmasında DFA kullanılmış ve ölçekteki 1, 2, 4, 7, ve 18. maddeler birden fazla gizil değişkene hizmet ettiği için ölçeğin Türkçe Formu' ndan çıkarılmıştır. Uyarlaması yapılan ölçek orijinalinde olduğu gibi kaygı, kontrol, merak ve güven alt ölçeklerinden oluşmaktadır. KUYÖ' nün Türkçeye uyarlanmış halinin alt ölçeklerinin (kayg1, kontrol, merak ve güven) Cronbach $\alpha$ değerleri sırasıyla $.83, .74, .79$ ve .85 bulunmuştur.

\subsubsection{Kişisel Bilgi Formu}

Araștırmacılar tarafından hazırlanan Kişisel Bilgi Formu'nda8 kapalı uçlu soru (cinsiyetiniz, yaşınız, okulunuz, bölümünüz, sınıfınız, annenizin mesleği, babanızın mesleği ve ailenizin aylık geliri) yer almaktadır.

\subsection{Verilerin Toplanması}

Araştırmanın verileri Dokuz Eylül Üniversitesi'nin çeşitli kampüslerinde gönüllük esasına dayalı olarak 2016-2017 Bahar Yarıyılında 2 aylık bir sürede toplanmıştır. Ölçeklerin tamamlanması 15-20 dakika sürmüștür.

\subsection{Verilerin Analizi}

Öğrenci Kariyer Yapılandırma Envanteri'nin her iki modele ilișkin yapı geçerliğini incelemek amacıyla DFA kullanılmıştır. Doğrulayıcı faktör analizi, değişkenler arasındaki hipotetik ilişkilerin değerlendirilmesinde ve alternatif modellerin uyum indekslerinin karşılaştırılmasında kullanılan bir yöntemdir (Kline, 1998).

DFA'da modeller kovaryans matriksi ve maksimum olasılık tahmini (maximum-likelihood estimation) kullanılarak Lisrel 8.30 paket programı ile analiz edilmiştir. Modellerin uyum indekslerini değerlendirmede aşağıdaki ölçütler kullanılmıştır: (1) uyum iyiliği indeksi (goodnessof fit index, GFI), $>.90,(2)$ karekök ortalama artık(square root mean residual) .10, (3) düzeltilmiş uyum iyiliği indeksi (adjusted goodness of fit index, AGFI) .90, (4) karşılaştırmalı uyum iyiliği indeksi (the comparative fit index, CFI) .95, (5) yaklaşık hataların ortalama karekökü (the root mean square error of approximation, RMSEA $)<.08$, ve 6w2istatistiksel serbestlik testi/derecesi(w2/df) 2 veya 3'ten daha düşük bir orana sahiptir $(\mathrm{Hu} \&$ Bentler, 1999).

DFA yapılmadan önce tek değişkenli normallik, çok değişkenli normallik ve doğrusallığa ilişkin varsayımların karşılanıp karşılanmadığı incelenmiştir. Normallik varsayımı Model 1 ve Model 2 için ayrı ayrı olmak üzere alt ölçeklerin her birine ilişkin basıklık çarpıklık katsayılarına göre incelenmiş ve bu değerler +1 ile -1 aralığında olduğundan tek değişkenli normallik varsayımının karşılandığı kabul edilmiştir (Çokluk, Şekercioğlu \& Büyüköztürk, 2010). Çok değişkenli normallik saçılma diyagramı matrisi ile incelenmiş ve elips şeklinde dağılımlar elde edildiği için çok değişkenli normallik sağlanmıştır. Doğrusallık için ise regresyon analizinden elde edilen artık grafiği ile incelenmiş ve bu grafikte noktalar sıfır çizgisi etrafında toplandığı için bu varsayımda karşılanmıştır.

Eş değer ölçek geçerliği kapsamında ÖKYE ve KUYÖ'nün alt ölçekleri arasındaki ilişkiler Pearson korelasyon analizi ile incelenmiştir.

Son olarak ölçeğin güvenirlik çalışması kapsamında ise Cronbach Alfa güvenirlik katsayısı hesaplanmıştır. Verilerin analizinde anlamlılık değeri olarak $\mathrm{p}<.05$ esas alınmıştır.

\section{BULGULAR}

\subsection{Yapı Geçerliğine İlişkin Bulgular}

Bu çalışmada ölçeğin geliştirildiği kültür ile Türk eğitim sistemindeki farklılıklar nedeniyle alternatif iki model test edilmiştir (Bkz. Şekil 1).

Model 1'e göre dört faktörlü modelin DFA ile test edilmesi sonucunda $\mathrm{X} 2=311.24, \mathrm{Sd}=129, \mathrm{x} 2 / \mathrm{sd}=$ 2.41, RMSEA $=.068, \mathrm{SRMR}=.056, \mathrm{RMR}=.075$, $\mathrm{GFI}=.90, \mathrm{CFI}=.90, \mathrm{AGFI}=.87$.olarak bulunmuştur. Analiz sonucunda elde edilen modifikasyon önerileri incelendiğinde madde 7 ve madde 9 arasındaki ilişkinin modelin uyum indekslerini olumsuz olarak etkilediği belirlenmiştir. Aynı faktör altında yer alan bu maddelerin anlamca birbirine yakın oldukları görülmektedir. Bu maddelere ilişkin hatalar ilișkilendirilerek DFA tekrar edildiğinde $\mathrm{X} 2=273.60, \mathrm{Sd}=128, \mathrm{x} 2 / \mathrm{sd}=2.13, \mathrm{RMSEA}=.061$, $\mathrm{SRMR}=.051, \mathrm{RMR}=.070, \mathrm{GFI}=.91, \mathrm{CFI}=.92$, $\mathrm{AGFI}=.88$. olarak bulunmuştur. Modifikasyon sonrasında Model 1'e ilişkin uyum iyiliği 


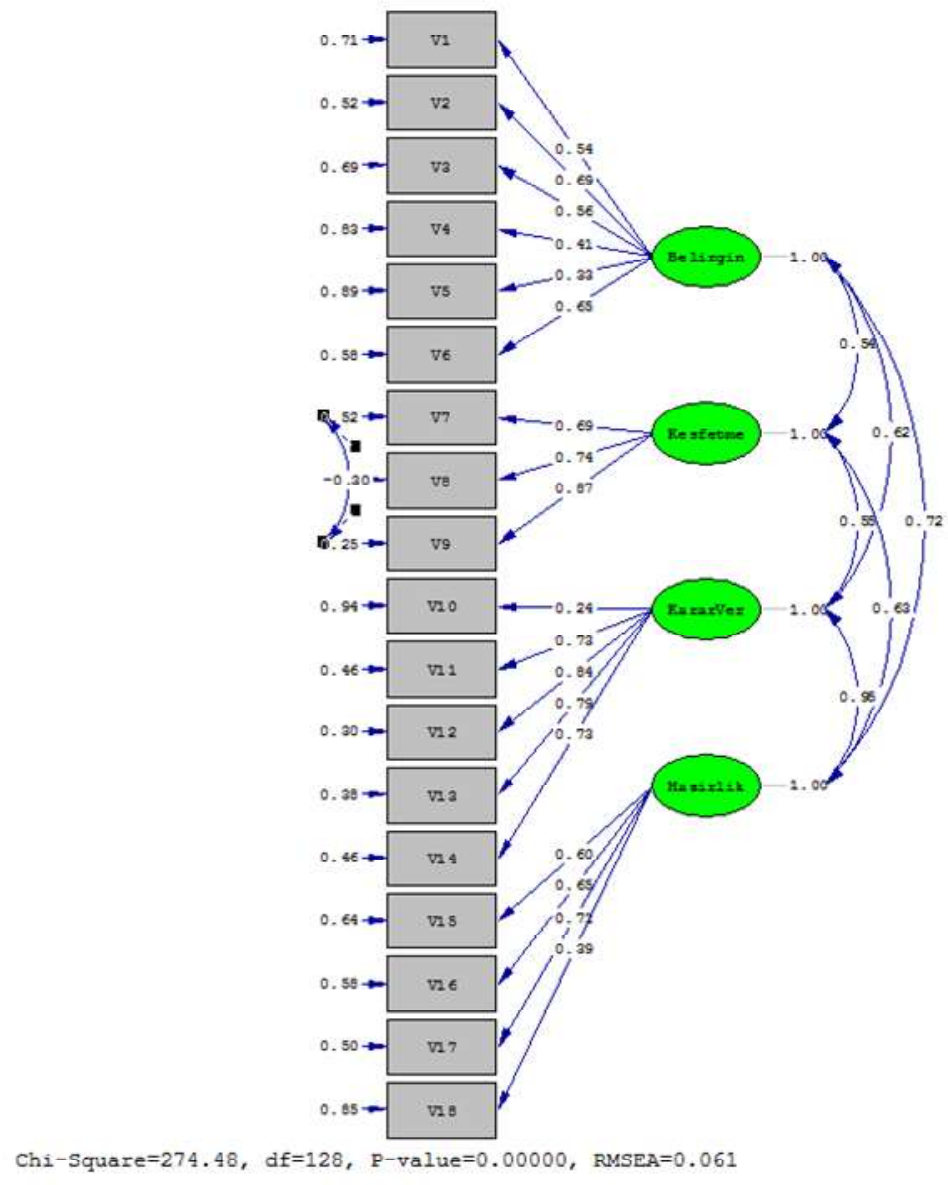

Sekil 2: Öğrenci Kariyer Yapılandırma Envanteri Birinci Ölçüm Modeli

indekslerinde bir iyileşme olmasına rağmen Şekil 2'de yer alan yol şeması incelendiğinde karar verme ve hazırlık alt boyutları arasındaki korelasyon değerinin .95 olduğu görülmektedir (Jöreskog \& Sörbom, 1993). Alt boyutlar arasındaki korelasyon değerinin .85'ten yüksek olması ayırt ediciliğin zayıf olduğunu göstermektedir. Bu yüzden bu iki alt boyutun birbirinden iyi bir şekilde ayrışmadığını söylemek mümkündür (Brown, 2006).

Model 2'ye göre üç faktörlü modelin DFA ile test edilmesi sonucunda $\mathrm{X} 2=321,86, \mathrm{Sd}=132, \mathrm{x} 2 / \mathrm{sd}=$ 2.43, $\mathrm{RMSEA}=.068, \mathrm{SRMR}=.058, \mathrm{RMR}=.074$, $\mathrm{GFI}=.90, \mathrm{CFI}=.90$ ve AGFI .87 olarak bulunmuştur. Analiz sonucunda elde edilen modifikasyon önerileri incelendiğinde madde 7 madde 9 ile Madde 12 Madde15 arasındaki ilişkinin modelin uyum indekslerini olumsuz olarak etkilediği belirlenmiştir. $\mathrm{Bu}$ maddelere ilişkin hatalar ilişkilendirilerek DFA tekrar edildiğinde uyum iyiliği indekslerinde artış olmuş ve Model 2 için $\mathrm{x} 2=256.39, \mathrm{sd}=130, \mathrm{x} 2 / \mathrm{sd}=1.97, \mathrm{RMSEA}=.056$, $\mathrm{SRMR}=.051, \mathrm{RMR}=.069, \mathrm{GFI}=.092, \mathrm{AGFI}=.89$ olarak bulunmuştur. Tüm değerler kabul edilebilir uyum indekslerine sahiptir.

\subsection{Eş Değer Ölçek Geçerliği}

ÖKYE'nin KUYÖ ile arasındaki korelasyon değerlerini incelemek amaciyla Pearson korelasyon analizi kullanılmıştır ve elde edilen bulgular Tablo 1'de yer almaktadır. Tablo 1'de görüldüğü gibi ÖKYE'nin belirginleştirme alt ölçeği ile KUYÖ'nün kayg1, kontrol, merak ve güven alt ölçekleri arasındaki ilişkinin sırasıyla $\mathrm{r}=.50, \mathrm{r}=$ $.47, \mathrm{r}=.41$ ve $\mathrm{r}=.41$ düzeyinde pozitif yönde anlamlı bir ilişki vardır. ÖKYE'nin keşfetme alt ölçeği ile KUYÖ'nün kaygı, kontrol, merak ve güven alt ölçekleri arasında sırasıyla $.41, .38, .32$ ve .35 düzeyinde pozitif yönde anlamlı bir ilişkiye sahip olduğu bulunmuştur. Son olarak ÖKYE'nin hazır olma ve karar verme alt ölçeği ile KUYÖ'nün kayg1, kontrol, merak ve güven alt ölçekleri arasında sirasiyla $.55, .39, .39$ ve .37 düzeyinde pozitif yönde anlamlı bir ilişkiye sahip olduğu sonucuna ulaşılmıştır $(p<0.01)$. 


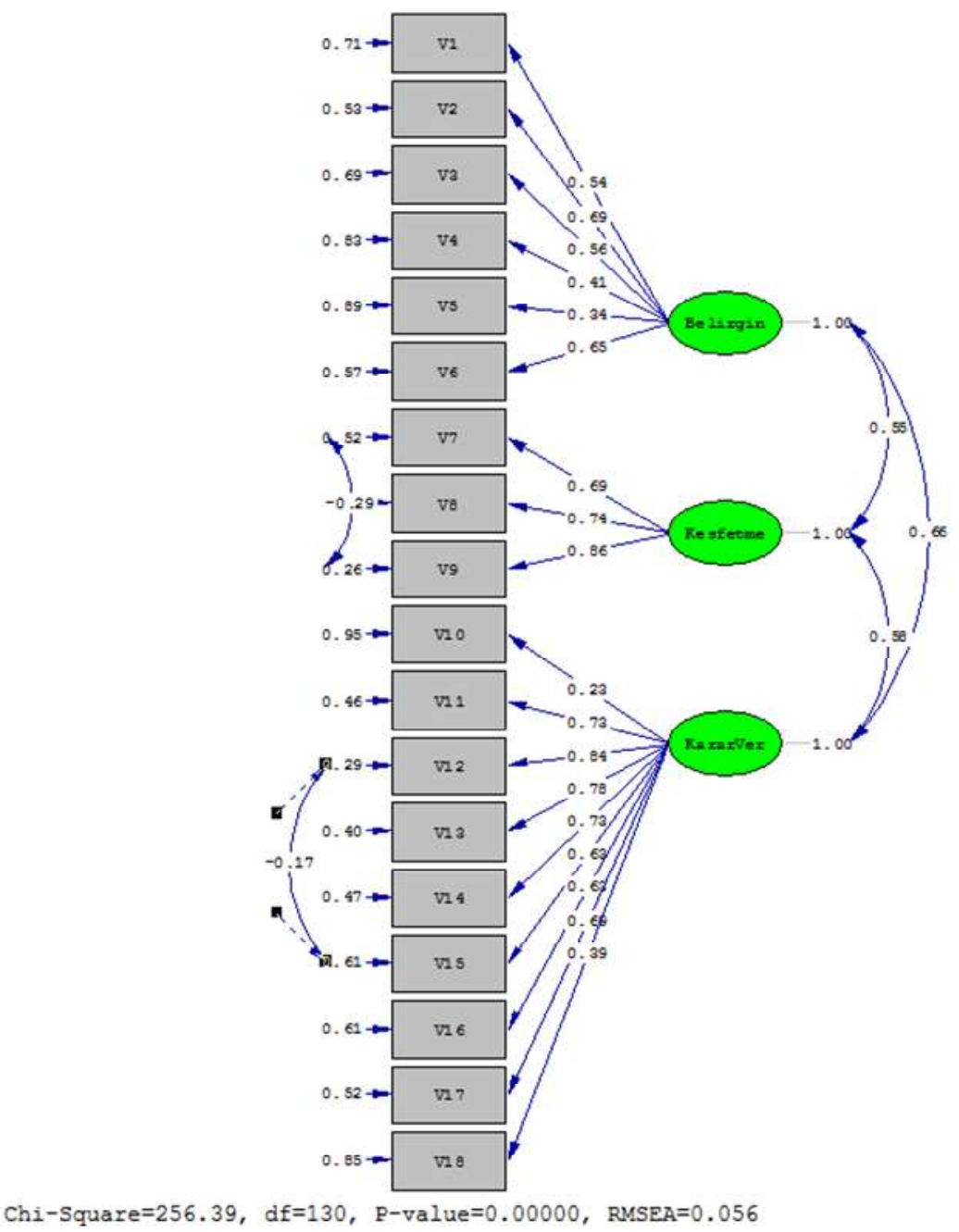

Sekil 3: Öğrenci Kariyer Yapılandırma Envanteri’nin Model 2 için Yol Șeması

\subsection{Güvenirliğe İlişsin Bulgular}

Türkçeye uyarlama çalışması yapılan ÖKYE'nin tamamı ve alt ölçekleri için Cronbach $\alpha$ güvenirlik katsayıları hesaplanmıştır. Dört alt boyuta sahip olan model 1'in tümü için Cronbach $\alpha$ değeri .87 olarak bulunurken "Belirginleştirme" alt boyutu için $\alpha=.65$, "Keşfetme" alt boyut için $\alpha=.72$ "Hazır olma" alt boyutu için $\alpha=.86 \mathrm{ve}$ "Karar verme" alt boyutu için $\alpha=.66$ bulunmuştur. Modifikasyon işlemi sonucunda elde edilen model 2'nin tamamı için Cronbachagüvenirlik katsayıs1 87 , "Belirginleştirme" alt boyutu için $\alpha=.65$, "Keşfetme" alt boyut için $\alpha=.72$,"Hazır olma" ve "Karar verme" alt boyutlarının birleştirilmesi sonucu oluşturulan üçüncü alt boyutun Cronbach $\alpha$ değeri ise .87 olarak hesaplanmıştır.

\section{TARTISMA}

$\mathrm{Bu}$ araştırmanın amacı Savickas ve arkadaşlarının (2018) tarafından geliştirilen ÖKYE'yi Türkçeye uyarlamaktır. Çalışma kapsamında ölçeğin yapı geçerliği, ölçüt geçerliği ve iç tutarlılığı incelenmiştir. 
Tablo 1: ÖKYE ve KUYÖ Alt Ölçekleri Korelasyon Katsayıları

\begin{tabular}{|c|c|c|c|c|c|c|c|c|}
\hline & & (1) & (2) & (3) & (4) & (5) & (6) & (7) \\
\hline (1) & Belirginleștirme & - & & & & & & \\
\hline (2) & Keșfetme & $.38^{* *}$ & - & & & & & \\
\hline (3) & Karar Verme & $.52^{* 8}$ & $.48^{* *}$ & - & & & & \\
\hline (4) & Kayg 1 & $.50^{* *}$ & $.41^{* *}$ & $.55^{* *}$ & - & & & \\
\hline (5) & Kontrol & $.47^{* *}$ & $.38^{* *}$ & $.39^{* *}$ & $.55^{* *}$ & - & & \\
\hline (6) & Merak & $.41^{* *}$ & $.32^{* *}$ & $.39^{* *}$ & $.69^{* *}$ & $.51^{8 *}$ & - & \\
\hline (7) & Güven & $.41^{* *}$ & $.35^{* *}$ & $.37^{* *}$ & $.51^{* *}$ & $.61^{* *}$ & $.49^{* *}$ & - \\
\hline
\end{tabular}

Ölçeğin geçerlik çalışması kapsamında yapı geçerliliği alternatif iki model üzerinde incelenmiştir. Model 1 ve Model 2 için DFA sonrasında elde edilen uyum indeksleri yeterli olmasına rağmen Model 1'de karar verme ve hazırlık alt boyutları arasındaki korelasyon değerinin .85 'ten yüksek olması, bu faktörlerin birbirinden yeterince iyi bir şekilde ayrışmadığını göstermektedir (Brown, 2006). Aslında bu şaşırtıcı bir durum değildir. ABD ile Türkiye'de ki üniversite sisteminin ve meslek seçme sürecinin farklılaşmasından dolayı bu iki faktörün ayrışmaması beklendik bir durumdur. Ölçek maddeleri de incelendiğinde bu faktörlerde yer alan maddelerin birbirleri ile benzeştiği görülmektedir. Örneğin Karar verme alt boyutunda yer alan 14 . Madde "İyi bir mesleki tercih yaptığım konusunda kendimden emin olmak" ile karar verme alt boyutunda yer alan 18. Maddenin "Beni tatmin edecek bir meslek seçmek" birbiriyle benzeşmektedir. Nitekim Model 2'de bu faktörlerin bir arada ele alındığında elde edilen daha iyi uyum iyiliği indeksleri ürettiği görülmektedir. Bununla birlikte giriş bölümünde bahsedildiği gibi ölçme aracının 25 maddelik formu başka dillere de uyarlanmıştır. Ryba ve arkadaşlarının (2016) tarafindan yapılan Fince'ye uyarlama çalışmasında da ÖKYE'nin 3 alt boyuta (belirginleştirme, keşfetme ve karar verme) sahip olduğu bulunmuştur. Model 2'de uyum iyiliği indekslerini yükselten iki modifikasyon işlemi yapılmıştır. Modifikasyon yapılan 7. Madde (Farklı iş türlerini öğrenmek) ile 9. madde (Bana uygun olabilecek meslekleri araştırmak) keşfetme boyutunda yer almaktadır. Modifikasyon yapılan 12. madde (Beni tatmin edecek bir meslek seçmek) ile 15. madde (İhtiyacım olan eğitim ve deneyimi elde etmemi sağlayacak firsatlar bulmak) ise Hazır Olma ve Karar Verme alt boyutunda yer almaktadir. Alan yazında da önerildiği üzere (Şimşek, 2007) aynı alt boyutta yer alan ve kuramsal olarak birbirlerine benzeyen maddeler olduğu için bu modifikasyonlar yapılmıştır. Modifikasyonlar sonrasında da Ki-kare değerlerinde 65.472'lik bir düşüşe yol açmış ve bu farkın istatistiksel olarak anlamlı olduğu görülmüştür.

Eş değer ölçek geçerliğine ilişkin bulgular genel olarak değerlendirildiğinde ÖKYE'nin alt boyutları ile KUYÖ'nün alt boyutları arasında pozitif yönde orta düzeyde ve düşük düzeyde anlamlı ilişkiler bulunmuştur. Kou, Tuncali ve Silverman'a (2003) göre $\mathrm{r}>$.50'nin üzerindeki korelasyon değerleri orta düzeyde bir ilişkiyi, $r>.30-.49$ arasındaki ilişki düşük düzeyde bir ilişkiyi göstermektedir. ÖKYE'nin 25 maddelik Portekizce (Rocha \& Guimaraes, 2012), İspanyolca (Merino-Tejedor vd., 2016), Hirvatça (Barbarović \& Šverko, 2016) uyarlamalarında da eş değer ölçek geçerliği için KUYÖ kullanılmış ve bu çalışmalarda da bu ölçekler arasında orta ve düşük düzeyde pozitif yönde anlamlı ilişkiler bulunmuştur. Ayrıca bu çalışma da Türkçe uyarlaması yapılan ÖKYE'nin 18 maddelik formu geliştirilirken de eş değer ölçek geçerliği için ÖKYE ile KUYÖ arasındaki ilişki incelenmiş ve orta düzeyde pozitif yönde anlamlı ilişkiler bulunmuştur (Savickas vd., 2018). Bu sonuçlar bir arada değerlendirildiğinde bu araştırmada elde edilen bulguların alan yazınla tutarlılık gösterdiği görülmektedir.

ÖKYE'nin KUYÖ ile arasındaki korelasyon değerlerini incelemek amaciyla Pearson korelasyon analizi kullanılmıştır ve elde edilen bulgular Tablo 1'de yer almaktadır. Tablo 1'de görüldüğü gibi ÖKYE'nin belirginleştirme alt ölçeği ile KUYÖ'nün kaygı, kontrol, merak ve güven alt ölçekleri arasındaki ilişkinin sırasıyla $.50, .47, .41$ ve .41 düzeyinde pozitif yönde anlamlı bir ilişki vardır. ÖKYE’nin Keşfetme alt ölçeği ile 
KUYÖ'nün kayg1, kontrol, merak ve güven alt ölçekleri arasında sırasıyla $.41, .38, .32$ ve .35 düzeyinde pozitif yönde anlamlı bir ilişkiye sahip olduğu bulunmuştur. Son olarak ÖKYE'nin Hazır Olma ve karar verme alt ölçeği ile KUYÖ'nün kayg1, kontrol, merak ve güven alt ölçekleri arasında sirasiyla $.55, .39, .39$ ve .37 düzeyinde pozitif yönde anlamlı bir ilişkiye sahip olduğu sonucuna ulaşılmıştır $(\mathrm{p}<0.01)$.

ÖKYE'nin güvenirliliği incelendiğinde tüm ölçek için Cronbach $\alpha$ değeri .88 bulunmuştur. Bu sonuç Ögrenci Kariyer Yapılandırma Envanteri'nin yüksek bir iç tutarlılığa sahip olduğunu göstermektedir. Araştırmadan elde edilen değerler ölçeğin uygulandığ 1 farklı ülkelerdeki çalışmalarla benzerlik göstermektedir (Barbarovic \& Sverko, 2016; Rocha \& Guimaraes, 2012; Ryba vd., 2016). Rocha ve Guimares (2012) tarafindan Portekizce'ye yapılan uyarlama çalışmasında Cronbach $\alpha$ değeri .89 bulunmuştur. Babarović ve Sverko'nun (2016) yaptığı Hırvatça'ya uyarlama çalışmasında lise birinci siniflardan elde edilen verilerin Cronbach $\alpha$ değeri .93 bulunurken lise son sınıf öğrencilerinden elde edilen verilerin Cronbach $\alpha$ değeri .89 bulunmuştur. Ryba ve arkadaşlarının (2016) yaptıkları Fince'ye uyarlama çalışması kapsamında belirginleştirme, keşfetme ve karar verme olmak üzere üç alt boyuttan ÖKYE'nin Cronbach $\alpha$ değerlerini sırasıyla .78, .77 ve .93olarak bulurken, ölçeğin tamamı için Cronbach alfa güvenirlik katsayısı .87olarak bulunmuştur.

$\mathrm{Bu}$ araştırma bulguları değerlendirilirken araştırmanın sınırlılıkları da göz önüne alınmalıdır. Araştırmanın sınırlılıklarından biri ölçeğin orijinalinden farklı olarak sadece lisans eğitimine devam eden öğrencilerle çalışılmış olmasıdır. Bundan sonra yapılan çalışmalarda lisansüstü öğrencileri için de geçerlik güvenirlik çalışmasının yapılması önerilmektedir. Araştırmanın bir diğer sınırlılığı geçerlik çalışması kapsamında sadece eş değer ölçek geçerliliği incelenmiş ancak ayırt edici ölçek geçerliliği incelenmemiștir. Araştırmanın sınırlılıklarına rağmen farklı fakültelere devam eden farklı sınıf düzeyindeki öğrencilerden veri toplanmış olması ve alternatif bir modelin test edilmiş olması çalışmanın güçlü yanlarını oluşturmaktadır.

Sonuç olarak, Türkçeye uyarlaması yapılan ÖKYE' nin üniversite öğrencilerinin mesleki davranışlarının düzeyini uygun şekilde ölçebilecek güvenirlik ve geçerlilik değerlerine sahip olduğu görülmektedir.

\section{KAYNAKÇA}

Bacanlı, F. (2011). Özellik faktör uyumlu kuramlar. İçinde B. Yeşilyaprak (Ed.), Mesleki rehberlik ve kariyer danışmanlığı (Beşinci baskı) (ss. 171-217). Ankara: Pegem Akademi.

Babarović, T. \& Šverko, I. (2016). Vocational development in adolescence: Career construction, career decision-making difficulties and career adaptability of Croatian high scholl students. Primenjena Psihologija, 9, 429-448.

Baş, G. (2016). Amerika Birleşik Devletleri Eğitim Sistemi: Karşılaştırmalı bir çalışma. Journal of Educational Sciences, 1(1), 63-93.

Brislin, R. W. (1970). Back-translation for cross-cultural research. Journal of Cross-cultural Psychology, 1(3), 185-216.

Brott, P. E. (2001). The storied approach: A postmodern perspective for career counseling. The Career Development Quarterly, 49(4), 304-313.

Brown, D. (2002). The role of work and cultural values in occupational choice, satisfaction, and success: A theoretical statement. Journal of Counseling and Development, 80, 48-56.

Brown, T. A. (2006). Confirmatory factor analysis for applied research. New York, NY: Guilford.

Çam, F. M. (2015). Sınıf öğretmenleri ve yöneticilerin yeni eğitim modeline $(4+4+4)$ ilişkin görüşleri (Pendik ilçesi örneği). Yayınlanmamış Yüksek Lisans Tezi. Yeditepe Üniversitesi, İstanbul.

Çokluk, Ö., Şekercioğlu, G. \& Büyüköztürk, Ş. (2010). Çok değişkenli istatistik SPSS ve LISREL Uygulamaları (1. Bask1). Ankara: Pegem Akademi Yayınları.

Dix, H. (2018). From writer's block to extended plot: Career construction theory and lives in writing. Journal of Life Writing, 1-16.

Gottfredson, L. S. (2002). Gottfredson's Theory of Circumscription, Compromise, and Self-Creation. İçinde D. Brown ve ark. (Ed.). Career Choice and Development (85-148). San Francisco: Jossey-Bass.

Hartung, P. J. \& Taber, B. J. (2008). Career construction and subjective well-being. Journal of Career Assessment, 16(1), 75-85.

Holland, J. L. (1966). The psychology of vocational choice: A theory of personality types and model environments. Massachusetts: Blaisdeel.

Holland, J. (1973). Making vocational choices A theory of careers. Englewood Cliffs: Prentice-Hall.

Hu, L. \& Bentler, P. M. (1999). Cut off criteria for fit 
indexes in covariance structure analysis: Conventional criteria versus new alternatives. Structural Equation Modeling, 6(1), 1-55.

Jöreskog, K. G. \& Sörbom, D. (1993). LISREL 8: Structural equation modeling with the SIMPLIS command language. Lincolnwood: Scientific Software International.

Kanten, S. (2012). Kariyer Uyum Yetenekleri Ölçeği: Geçerlilik ve güvenilirlik çalışması. Süleyman Demirel Üniversitesi Sosyal Bilimler Enstitüsü Dergisi, 2(16), 191-205.

Kline, R. B. (1998). Principles and practice of structural equation modeling. New York: Guilford.

Korkut-Owen, F. \& Niles, S. G. (2011). Yeni yaklaşımlar ve modeller. İçinde B. Yeşilyaprak (Ed.). Mesleki rehberlik ve kariyer danışmanlığı (ss. 274-305). Ankara: Pegem.

Kou, K. H., Tuncali, K. \& Silverman, S. G. (2003). Correlation and simple linear regression. Statistical Concepts Series, 227, 617-628.

Kozak, M. A. \& Dalkıranoğlu, T. (2013). Mezun öğrencilerin kariyer algılamaları: Anadolu Üniversitesi örneği. Anadolu Üniversitesi Sosyal Bilimler Dergisi. 13(1), 41-52.

Kuzgun, Y. (2006). Meslek Rehberliği ve Danışmanlı̆̆ına Giriş (3. Baskı). Ankara: Nobel Yayınevi.

Külekçi, E. \& Bulut, L. (2010). Türkiye ve ABD’ deki Öğretmen Yetiştirme Sistemlerinin Karşılaştırılması. International Conference on New Trends in Education and Their Implications, Antalya, Turkey.

Maree, J. G. (2010). Brief overview of the advancement of postmodern approaches to career counseling. Journal of Psychology in Africa, 20(3), 361-368.

Maree, J. G. (2015). Career construction counseling: A thematic analysis of outcomes for four clients. Journal of Vocational Behavior, 86, 1-9.

Merino-Tejedor, E., Hontangas-Beltran, P. M. \& BoadaGrau, J. (2016) Career adaptability and its relation to self-regulation, career construction, and academic engagement among Spanish university students. Journal of Vocational Behavior, 93, 92-102.

The Condition of Education 2003. (2018, 3 Ocak) Erişim adresi: https://nces.ed.gov/pubs2003/2003067.pdf

Osborn, D. S. \& Zunker, V. G. (2002). Using assesment results for career development. Boston: Cengage Learning.

Özyürek, R. (2013). Kariyer psikolojik danışmanlığg kuramları: Çocuk ve ergenler için kariyer rehberliği uygulamaları. Ankara: Nobel Yayıncılık.

Patton, W. \& McMahon, M. (1999). Career development and systems theory: A new relationship. Thomson Brooks/Cole Publishing Co.

Polat, E. (2008). Türkiye'nin demografik yapısı içinde eğitim ekonomisinin yeri ve önemi 8Yayınlanmamış Yüksek Lisans Tezi). Dokuz Eylül Üniversitesi, İzmir.

Rocha, M. \& Guimaraes, M., I. (2012). Adaptation and psychometric properties of the student Career Construction Inventory for a Portuguese sample: Formative and reflective constructs. Psychological Reports: Measures and Statistics, 111(3), 845-869.

Ryba, T. V., Zhang, C. Q., Huang, Z. \& Aunolaa, K. (2016). Career Adapt-Abilities Scale - Dual Career Form (CAAS-DC): Psychometric properties and initial validation in high-school student-athletes. Health Psychology and Behavioral Medicine, 5, 85100 .

Savickas, M. L. (2002). Career construction: A developmental theory of vocational behavior. İçinde D. Brown ve ark. (Ed.), Career choice and development (ss. 149-205). San Francisco: JosseyBass.

Savickas, M. L. (2005). The theory and practice of career construction. İçinde R. W. Lent, \& S. D. Brown (Ed.), Career development and counseling: Putting theory and research to work. Hoboken (ss. 42-70). New Jersey: John Wiley \& Sons.

Savickas, M. L., Nota, L., Rossier, J., Dauwalder, J. P., Duarte, M. E., Guichard, J., vd., (2009). Life designing: A paradigm for career construction in the 21 st century. Journal of vocational behavior, 75(3), 239-250.

Savickas, M. L., \& Porfeli, E. J. (2012a). Student Career Construction Inventory. Rootstown, OH: Vocopher.com

Savickas, M. L. \& Porfeli, E. J. (2012b). Career AdaptAbilities Scale: Construction, reliability, and measurement equivalence across 13 countries. Journal of Vocational Behavior, 80(3), 661-673.

Savickas, M. L., Porfeli, E. J., Hilton, T. L. \& Savickas, S. (2018). The student career construction inventory. Journal of Vocational Behavior, 106, 138-152.

Sharf, R. S. (1992). Applying career development theory to counseling. Belmont: Brooks Cole

Super, D. E. (1953). A theory of vocational development. American Psychologist, 8(5), 185-190.

Super, D. E. (1975). Career education and career guidance for the life span and for life roles. Journal of CareerEducation, 2(2), 27-42.

Super, D. E. (1980). A life-span, life-space approach to career development. Journal of Vocational Behavior, 16(3), 282-298. 
Şimşek, Ö. F. (2007). Yapısal eşitlik modellemesine giriş (Temel ilkeler ve LISREL uygulamaları). Ankara: Ekinoks.

Yeşilyaprak, B. (2011). Mesleki rehberlik ve kariyer danışmanlığına giriş. İçinde B. Yeşilyaprak (Ed.), Mesleki rehberlik ve kariyer danışmanlı̆̆ (Beşinci bask1) (ss. 1-41). Ankara: Pegem Akademi.

Yılmaz, O. (2016). Üniversite öğrencilerinin kariyer yönelimlerinin "Kariyer Dünyası Haritası" üzerinde karma desenle incelenmesi: Psikolojik danışma ve rehberlik örneği (Yayınlanmamış Doktora Tezi). Hacettepe Üniversitesi, Ankara.

\section{Ek-1. Öğrenci Kariyer Yapılandırma Envanteri}

1. Kişiliğimin net bir resmini oluşturmak

2. Yeteneklerimi ve becerilerimi tanımlamak

3. Benim için önemli olan değerleri belirlemek

4. Diğer insanların beni nasıl gördüğünü bilmek

5. Benzemek istediğim insanları belirlemek

6. İlgi alanlarımı bulmak

7. Farklı iş türlerini öğrenmek

8. Meslekler hakkında bilgi edinmek

9. Bana uygun olabilecek meslekleri araştırmak

10. Yaşamak için gerçekten ne yapmak istediğime karar vermek

11. Bana uyan bir iş alanı bulmak

12. Eğitimimi tamamladıktan sonra bir işe girmek

13. Seçtiğim mesleğe nasıl gireceğimi planlamak

14. İyi bir mesleki tercih yaptığım konusunda kendimden emin olmak

15. İhtiyacım olan eğitim ve deneyimi elde etmemi sağlayacak firsatlar bulmak

16. Tercih ettiğim iş için ihtiyacım olan eğitime başlamak

17. En çok hoşuma giden işi belirlemek

18. Beni tatmin edecek bir meslek seçmek 